\title{
WOMEN'S POLITICAL EMPOWERMENT IN URBAN LOCAL GOVERNMENT: A STUDY ON CUMILLA CITY CORPORATION
}

\author{
Jannatul FERDOUS 1 \\ Ali AJGOR 2 \\ Nur MOHAMMAD 3
}

\begin{abstract}
Empowerment or involvement of women in leading procedure through gender complex specific policies are the precondition for attaining supportable progress in any emerging state, for instance Bangladesh. Constitutional requirements of Bangladesh can be seen as the landmark on the way to guaranteeing women's equivalent entrance and amplified involvement in political authority arrangement at City Corporation layer to consolidate the local government also for the supportable progress of Bangladesh. It implies direct partaking of the people in instituting the local body and management of the matters of such organizations as well. However, constitutionally we are succeeding the local government structure in all tiers, on the other hand, not performing it appropriately in the true sense. Comilla is one of the ancient towns of the sub-continent. In the year of 1864, it was stated municipality and in 2003, Comilla Sadar Dhakin Pourashava was acknowledged. Through put an end to these two pourashavas and containing their regions, the announcement of the Comilla City Corporation happened on 10 July 2011. It was the historical event for Comilla City. In 5th January 2012, the first ever election was held of Comilla City Corporation. The second election was held successfully, on 30 March 2017. The current study was carried out on Comilla City Corporations twenty-seven wards of nine ward councilors of the reserved seat. All of them were elected from three wards by direct vote and participation of voters both men and women. The representatives were elected for five years. The key aim of this research is to carefully measure the contemporary situation of empowerment of women councilor of the ward from reserved seats.
\end{abstract}

Key words: women, empowerment, politics, local government, City Corporation, Bangladesh.

\footnotetext{
1 Assistant Professor, Department of Public Administration, Comilla University, Cumilla, Bangladesh, Email: jannat.lata@yahoo.com

2 M. S. S. Student, Department of Public Administration, Comilla University, Cumilla, Bangladesh, Email: rakibhasanlak1002@gmail.com

${ }^{3}$ M. S. S. Student, Department of Public Administration, Comilla University, Cumilla, Bangladesh, Email: nurmohammadcou97@gmail.com
} 
74 Women's political empowerment in urban local government

\section{Introduction}

The inclusive development of a state hang on highest deployment of her citizens, both male and female. In Bangladesh, women consist almost half of the entire population. However, the position of women is at a much below level than that of male in every realm of life. Women are recognized with familial life whilst politics is observed as a male directed public function that is basically masculine purely (Hossain, 2015). Empowerment as a recurrently used catch phrase takes diverse practices. It is, generally expressing, a societal issue that supports individuals or clusters to be efficient or more enabled to take greater charge of their everyday lives (Zaman, 2012). Women ward councilors represented in reserved seats in urban local government institutions are playing a significant role in diverse segments, particularly in women related matters (Taskin, 2015). The Constitution of Bangladesh commenced clauses to protect the rights women and keep provisions ensuring women's equal rights. Article number 19, $27,28,29$ and 65 of the Constitution take care of women's equal rights and their involvements in the in all aspects of the national life. Clause 3 of Article 65 of the Constitution contends with the provision of reserved seats in the Parliament (GoB, 2016). However, the scenario of women's representation is still very below level in Bangladesh, particularly in Cumilla City Corporation. The reason of under representation is assigned to many issues like lack of education, financial inability, family liabilities, religion, stereotypes in society, electoral mechanism, party belief, psychological obstacles (lack of assertive power, low level of self-esteem) etc. (Rahman, 2015). Women's equivalent involvement in political life plays a significant role in the general procedure of the improvement of state. It is not simply a demand for appropriate justice or representing democracy but can also be observed as an essential requirement for women's interests to be taken into consideration.

Here, in this research, women's involvement is not simply about representation in local government institutions, however, is concerned with their empowerment of women through their participation. This study seeks to identify the role of female ward councilors of reserved seats as per the present structure and functions of urban local government institution and obstacles encountered by female ward councilors of reserved seat in performing duties and responsibilities.

\section{Objectives of the Study}

$>$ To assess the role of female ward councilors of reserved seats as per the present structure and functions of urban local government institutions (e.g. city corporations).

$>$ To identify obstacles encountered by female ward councilors of reserved seat in performing duties and responsibilities.

$>$ To suggest some possible recommendations to overcome the difficulties in performing duties and responsibilities. 


\section{Rationality of the Study}

In Bangladesh, women live in a societal arrangement where the socialization procedure plays a persuasive role in force them into a lower and inferior position in society. This socialization procedure initiated almost with the born of a child. This socialization procedure links girls with the household and boys with a larger atmosphere. This outcome in an uncomplimentary view of female with regard to politics (Siddika \& Rahman, 2008). Women's political involvement has turned to be an attention of all global institutions' advocacy activities. Vital inputs have been generated by these institutions to develop women's political involvement universally. At the local level, women's political involvement is presently an extensively discussed issue universally (Sarker, 2018). An UN study viewed that the level of progress of a state as revealed by its demographic and social issues confined the involvement of women in politics. In those states where women's illiteracy is tremendously noteworthy along with below living standards and high rates of fertility, the possibility of women's participation is considerably less (UN, 1992). Without the lively involvement of women and the inclusion of women's evaluation at every layers of decision-making, the purposes of equality, progress and peace cannot be accomplished (Siddika \& Rahman, 2008).

The validity of democratic governance hang on the equal involvement of both male and female in decision-making procedure and public administration (Sun, 2004). It is claimed that female can play their active role in the promotion procedure essentially. Women's impact to the advancement of the community and nation-building hang essentially on their involvement in both family matters and national level decisionmaking procedure (Chowdhury, 2002). Good urban local government institutions require consideration to a quantity of significant points, for instance, responsibility, transparency, accountability, responsiveness, rule of law, democratic involvement, decentralization, management, proficiency, encouragement, and leadership of female representatives (Zaman, 2007). However, the matter is that the elected women ward councilors (reserved seats) of Cumilla City Corporation do not receive the actual political authority in their actual life. Generally, the male councilor thinks that they (women ward councilor of reserved seat) are only play an ornamental role in politics. They cannot participate or provide opinion in any significant committee lively. In the standing committee meeting they can play a role of an observer only. They cannot communicate to any monetary functions. Therefore, this study is significant to find out the real condition of women in footings of their duties, tasks, and authority. The findings of the study can also helpful for the public policy maker to take appropriate steps to recover the negative situation.

\section{Scope of the Study}

This study provides the scope for a close observation of the role and responsibilities of female elected representatives in decision-making processes at the city corporation level. It has made an attempt to comprehend the influencing factors that hampers women representatives to complete their duties and responsibilities. This study has not simply assessed the issues that affect women's participation, but it has also validated the 
76 Women's political empowerment in urban local government

level of participation of women representatives in local government institutions in Bangladesh. Scope of the study is shown in following figure.

\section{Figure 1. Scope of the study}

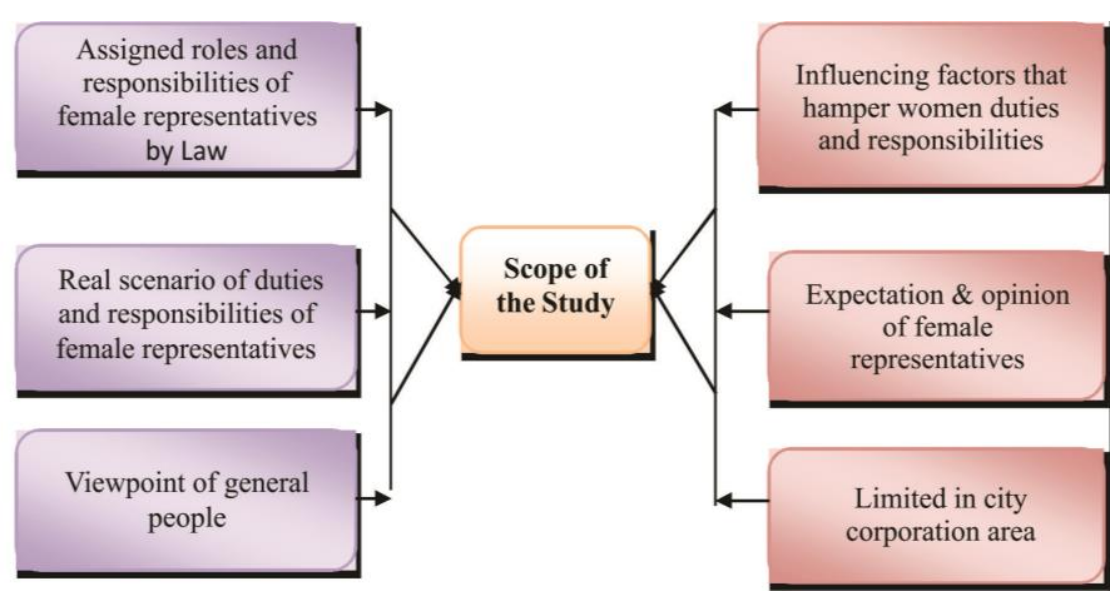

This study is practically confined within the matter of women's involvement in the local governments. Geographically, it is confined to City Corporation, but the inferences can analytically be discussed to other LGIs in the state as the factors, situations and impacts affecting the assessments and practices of the samples utilized may have a similar impact to other individuals and areas.

\section{Methodology}

Cumilla City Corporation is selected as a study area. It is a newly developed City Corporation. In this study total 100 people were selected from this area through simple random sampling method. Respondents list are below:

Table 1. Category and Number of Respondents

\begin{tabular}{|l|c|}
\hline Category of sample & Total number \\
\hline Elected women representatives & 5 out of 9 \\
\hline Service providers \& male councilors & $2+3=5$ \\
\hline General citizen & 90 \\
\hline Total & 100 \\
\hline
\end{tabular}


Several techniques were utilized for data collection in this study. The crucial data collection techniques were used in this study was interview and focused group discussion. The secondary sources of data were in the form of published documents. The study utilized several sources to assemble secondary data, for instance, from diverse relevant publications, dissertations, books, journal articles, reports, websites etc. and other pertinent documents were taken into consideration. Secondary sources were very significant to relate the relationship between dependent and independent variables.

\section{Limitation of the Study}

Owing to time and resource obstacles, it was hard to accomplish a research on entire population and elected man and women representatives at the urban level, for instance, city corporation in general. Therefore, a small cluster of respondents was selected from the entire population by random sampling. To overcome the problems of the study, case studies and in-depth interviews, observations have been taken into account. Therefore, it has been actually perplexing to address the entire methodology within very limited time for collection of data. Conversely, women ward councilors from the reserved seat were not well communicated and unable to disclose adequate information about the matter situated within their particular workstation.

\section{Literature Review}

To accomplish this study following books, several journals and research reports were studied.

Hasan (2007) in his study, "Women in Bangladesh Local Government: A Study of Gram Sarker" realized that, in the face of Constitutional undertakings, female in Bangladesh were not considered equivalently. A patriarchal societal arrangement, purdah (veil), marriage and religious obstacles located them in an unbalanced and unfortunate position. Women persisted prevented from decision-making and efficient political involvement. Their potentialities and inputs were frequently unnoticed and ignored because of male control and other socio-cultural obstacles that performed against female's active involvement in political procedure.

Panday (2008) conducted a study, "Representation without Participation: Quotas for Women in Bangladesh" on women's involvement in decision-making procedure at the national, along with the Union Parishad level. He found diverse issues that obstructed women's political involvement in the political procedure: educational insufficiency; lack of financial resources; deficient movement; structural inadequacies; culture backwardness; religion and patriarchal difficulties. He observed that there was a latest deterioration of the number of females fighting quota seats. He anticipated that this may possibly be due to previous female candidates faced embittered experiences. From his research, it is apparent that the reservation of quota for the political involvement of female in the local government institutions does not confirm their vigorous involvement in the decision-making. 
Moin (2011) in her study "Empowerment of Women and their Participation in Local Government Politics" found that, in a male-controlled political extent, the patriarchal societal scheme, reasonable provision from family, monetary capability, 'purdah' was contemplated as significant obstacles for women's political involvement in Bangladesh. She found that female did not gain an equal serving of projects and that their capabilities were not appreciated by their male complements. She specified that, being minor representation in the LGIs, they were not capable to effect decision-making or to acquire control over any assets. To Moin (2011), elected female generally fails to accomplish their election promises, which generate a undesirable impression amongst the voters.

Panday (2013) in his study “Women's Political Participation in Bangladesh: Institutional Reforms, Actors and Outcomes" found that socio-cultural difficulty, organizational insufficiencies, and attitudinal complications hampered women's political involvement. This study also perceived that the political parties were not preemptive in respect to females' involvement in politics. The depiction of the Union Parishad Act, 1997 had delivered a greater opportunity for females to contribute in politics, particularly in UP elections and UP decision-making. Their number of representations has been confirmed but their actual involvement has not yet been confirmed.

Panday (2016) in his study “Women's Empowerment in South Asia: NGO Intervention and Agency Building In Bangladesh" found that systems amongst females, entrance to have information, capacity-development training, amplified understanding and expertise and approaches of possession acted an effective role to create females confident and conscious about contributing in development accomplishments, in addition to helped them to increase their influences in the decision-generating of Union Parishads (UP). According to Panday (2016), the UPs were currently apt more gender-receptive in their actions.

Chowdhry \& Aktaruzzaman (2016) in their study "Citizen participation in urban local government: a case study of Kanaighat Paurashava in Bangladesh" desired to recognize the particular issues that function as drivers for citizen involvement in Bangladesh by a case study of Kanaighat Paurashava (municipality) which is an urban local government institution. It recognized some variables which highly distress citizen's involvement. These are including the activities of the elected representatives, remarkably their inclination and consciousness; the facility of information to common citizens; citizens' capability; and accessible resources. Findings also offered that a comprehensive approach was essential to comprehend and transform representatives' outlooks towards citizens and confirm involvement.

Muhammed (2017) in “Women's Political Participation in Local Government in Ethiopia: The Case of Two Districts in Amhara Regional State", observed that some women in councils head standing committees as male had the a greater representation in all of the standing committees. Female were lagging behind in choosing to the leading points. The study also identified that, frequently, local administrators did not rely on the capability of women. According to Muhammed (2017), the persisting patriarchal opinions and gender preference in society were the key reasons of averting better women's involvement. 
Sarker (2018) in his article "Participation of Female Vice-Chair in decision-making process at Upazila Parishad, Bangladesh" assessed women's involvement in decisionmaking procedure concerning project choice, execution and arrangement in UZP meetings comprising (s) committee meetings to evaluate the level of females' participation. The contemporary condition of women's decision-making has been examined with their distribution of assessments, views and suggestions in UZP decision-making and with the acceptance of such suggestions. The research outcomes exposed that, in UZPs, elected female delegates have commenced to affect the decision-making procedure. It specified that area for female has been shaped to some degree notwithstanding some organizational insufficiencies and socio-cultural obstructions. This research also exposed that the influence of guidelines, regulations and training has reflective effect on women's involvement.

Ullah (2018) in his study “Local Government in Bangladesh: Women's Participation and Empowerment" tried to critically assess the magnitude of women's political involvement and in the local level institution like Union Parishad in Bangladesh The paper was basically enablement grounded on the assessment of secondary tools. The research findings recommended that the actual picture is not so good after passing the two decades of such an admirable footstep. Owing to societal, political, and cultural obstacles, elected female members in local government organizations cannot play their influencing role.

Table 2. Summary of Literature Review on Women's Political Participation

\begin{tabular}{|l|l|}
\hline \multicolumn{1}{|c|}{ Name of Authors } & \multicolumn{1}{|c|}{ Major Findings } \\
\hline Hasan (2007) & $\begin{array}{l}\text { Male domination and male-controlled societal norms impede } \\
\text { women's leadership. }\end{array}$ \\
\hline Panday (2008) & Quota does not endorse active involvement in decision-making. \\
\hline Moin (2011) & $\begin{array}{l}\text { Male representatives are not conscious of their roles and } \\
\text { obligations. }\end{array}$ \\
\hline Panday (2013) & $\begin{array}{l}\text { Act of 1997 carries prospects for women to insert politics } \\
\text { although little influence for them. }\end{array}$ \\
\hline Panday (2016) & Despite male supremacy, women are fostering their voices. \\
\hline Chowdhry \& & $\begin{array}{l}\text { An all-inclusive method was desired to comprehend and } \\
\text { modification representatives' outlooks regarding citizens and } \\
\text { confirm involvement. }\end{array}$ \\
\hline Muhammed (2017) & Less trust in the capability of women. \\
\hline Sarker (2018) & $\begin{array}{l}\text { Elected female representatives have commenced to impact the } \\
\text { decision-making procedure and rules, laws and training has deep } \\
\text { impact on women's involvement. }\end{array}$ \\
\hline Ullah (2018) & $\begin{array}{l}\text { Owing to social, political and cultural obstacles, elected women } \\
\text { members in local government organizations cannot play an active } \\
\text { role. }\end{array}$ \\
\hline
\end{tabular}


The foregoing discussions on pertinent literature provide a broad focus about women's contemporary status, their empowerment and participation in the political extent in the ground of national (LGIs) and global levels. However, in this study key focus will be provided on role of women ward councilors in reserved seats as in accordance with the contemporary structure and activities of urban local government organizations (e.g. Cumilla city corporations) and difficulties faced by female ward councilors of reserved seat in functioning duties and responsibilities.

\section{Representation of Women in the City Corporations in Bangladesh}

Although Bangladesh constitution delivers proper parity of male and female. Our constitution Article 28(2) stated that "Women shall have equal rights with men in all spheres of state and public life". In Article 29(3) indicated that "Steps shall endeavor to ensure equality of opportunity and participation of women in all spare of national life" (GoB, 2016).

However, women are differentiated for lots of reasons for example, male councilors of the general seat allotted certain unwritten directions. Women's representation in reserved seats lack the responsiveness of their obligations and responsibilities. In the reserved seats of women, councilors were elected from three wards, through passing many hindrances. Yet, if elected can organize certain work for the wellbeing of the individuals, she cannot do developmental effort that approach. In this circumstance, it is not the law, although the elected male councilors of the general seat seem to be the foremost difficulty (Bangladesh top gender equal, 2018).

There is an extensive consent that women's augmented participation in politics is essential for both the democratic progress of the country, along with women's advancement in Bangladesh. However, the election result of City Corporation is entirely different from national level election. When, there is no female elected representative in City Corporation without reserved seats.

Table 3. Women representation scenario in city corporation elections

\begin{tabular}{|l|l|l|l|}
\hline \multicolumn{1}{|c|}{ Year } & \multicolumn{1}{|c|}{$\begin{array}{c}\text { Name of city } \\
\text { corporation }\end{array}$} & Male councilors & \multicolumn{1}{c|}{$\begin{array}{c}\text { Reserved seats of } \\
\text { women }\end{array}$} \\
\hline $\mathbf{2 0 1 7}$ & Cumilla & 27 & 09 \\
\hline $\mathbf{2 0 1 5}$ & Dhaka north & 54 & 18 \\
\hline $\mathbf{2 0 1 5}$ & Dhaka south & 57 & 19 \\
\hline $\mathbf{2 0 1 7}$ & Gazipur & 57 & 19 \\
\hline $\mathbf{2 0 1 7}$ & Chittagong & 41 & 14 \\
\hline $\mathbf{2 0 1 7}$ & Khulna & 31 & 10 \\
\hline
\end{tabular}

Source: Election commission report, 2019 


\section{Analytical Framework}

Dependent and independent variables have been widely drawn from the prevailing literature. The dependent variable is women political empowerment at City Corporation. Independent variables are broadly classified as Socio-economic, sociocultural, and institutional structure. Socio-economic variables include age; educational attainment; income; marital status, family size of women. Institutional structure includes rules, regulation, customs, and norms. The variables that are identified as key determinants of women empowerment at City Corporation are Socio-economic, institutional structures and resources. Here within the framework, an effort has been drawn to point out the casual links between these variables.

Figure 2. Analytical Framework of the Study

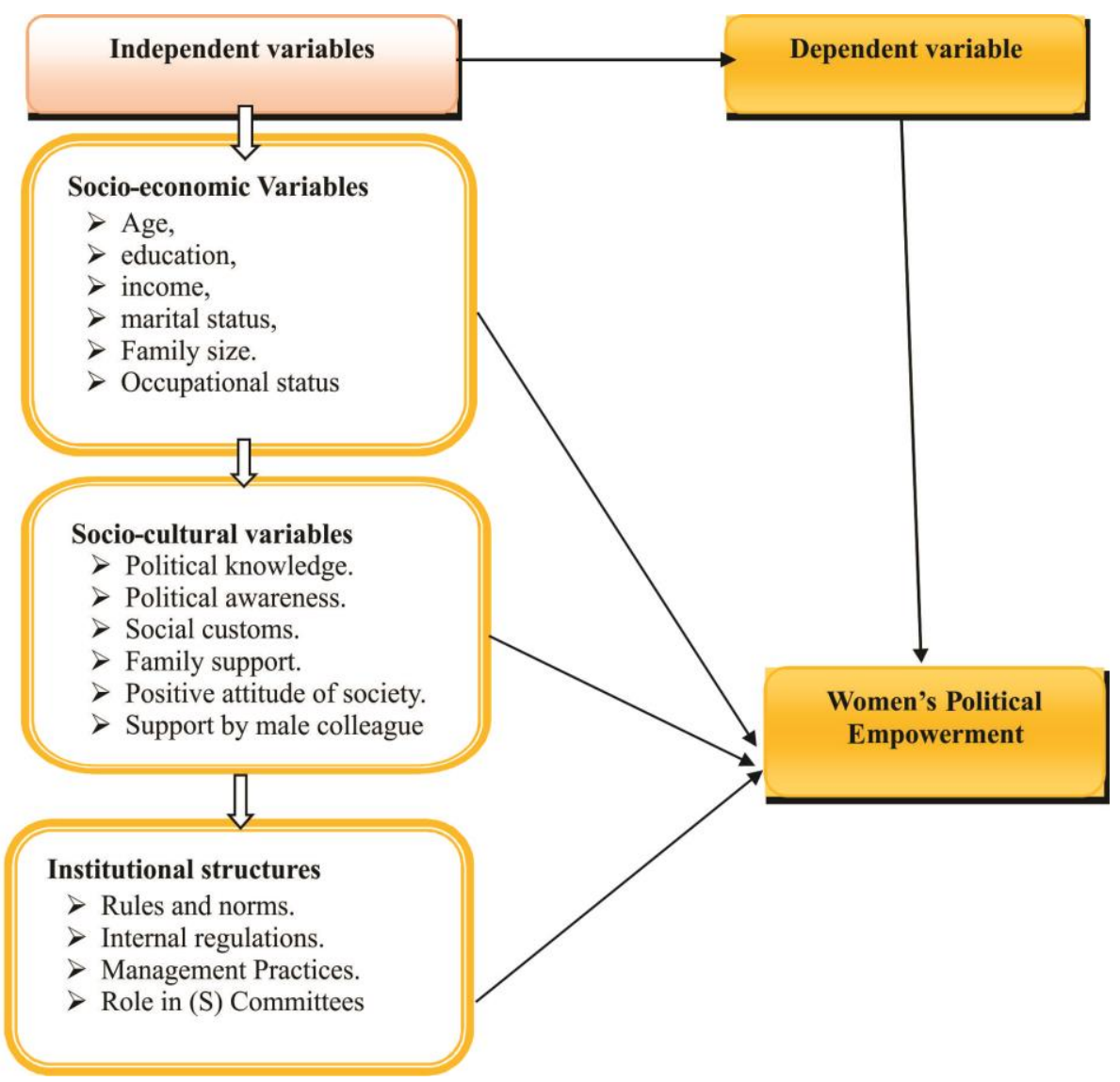


82 Women's political empowerment in urban local government

\section{Discussion and Analysis}

Responses about reasons/factors that inspired you to participate in Local government City Corporation election:

Women are the half of the total population of the country. Holistic development is impossible without women participation in political, economic, and social system. Government has taken various measures for women political participation. From the above table, it is represented that three female councilors participated in city corporation election by the inspiration of family member. Two opined that they inspired by the people of locality. Two councilors were inspired by political party and only one councilor called he got inspiration by the rural development program and training of BARD.

Table 4. Responses regarding participation

\begin{tabular}{|l|c|}
\hline 1. Self-inspiration & $\mathbf{2}$ \\
\hline 2. Inspired by family members & 3 \\
\hline 3. Inspired by the people of the locality & $\mathbf{2}$ \\
\hline 4. Inspired by the political party & 2 \\
\hline 5. Inspired by rural development program of BARD & $\mathbf{1}$ \\
\hline
\end{tabular}

Responses about institutional roles $\mathcal{E}$ responsibilities of a women councilor in City Corporation

According to female councilors their main roles and responsibilities are following:

$>$ Development of Public health.

$>$ Residential Project Development.

$>$ Community Development.

$>$ Slum improvement.

$>$ Water and sanitation.

$>$ Educational \& cultural development.

$>$ Social Welfare.

$>$ Attend the city corporation meeting.

$>$ Monitoring the city corporation projects of respective area. 


\section{Female councilor's response about the level of adequacy of institutional rules and regulations}

Women elected representatives are deemed as a strong agent for realizing the actual problem of urban women. They work following institutional rules of City Corporation. Two respondents opined that institutional rules are adequate for performing their duties. One respondent called it is highly adequate. Another person called it is moderate. Finally, a single person responded institutional rules is little adequate for performing duties and responsibilities. Because, people' expectation is high than city corporation manual and they cannot fulfill new demands of citizens.

Figure 3. Responses regarding institutional rules and regulation

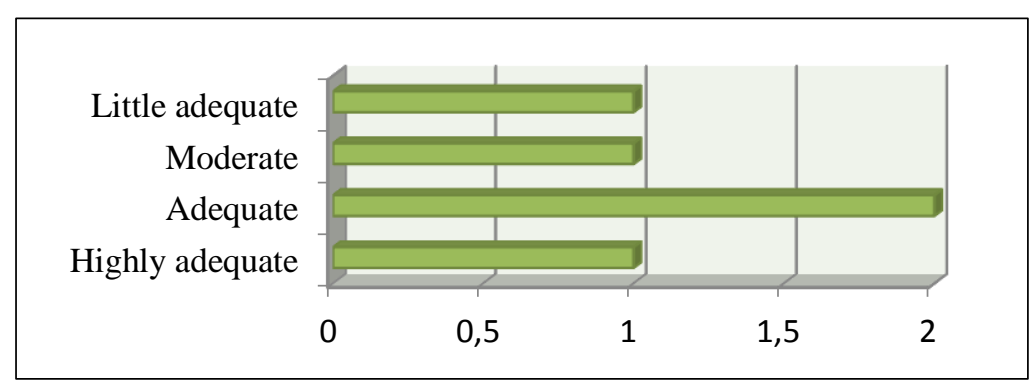

\section{Female councilor's response about structural problems in performing your duties E responsibilities}

Our society is male dominated society. In every sectors male enjoy better opportunities than female. In city corporation female face much structural problems. Three respondents opined that structural problem is high. There is no clear indication/instruction of their duties and responsibilities. As a result, they cannot work properly due to male dominance. One respondent called it is moderate. Finally, a single respondent called institutional problem is very little. He called institutional rules does not hinder in doing work.

Figure 4. Responses regarding structural problems

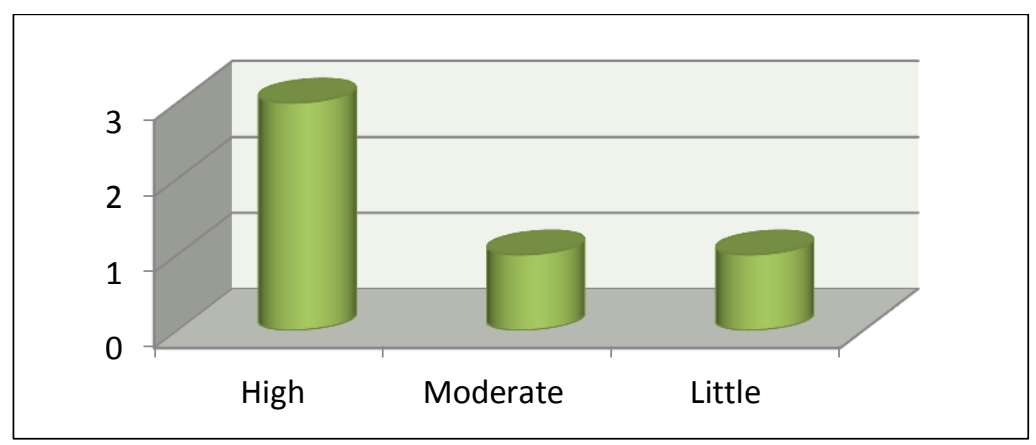




\section{Female councilor's response about the barriers of their family in performing duties E responsibilities}

This study was conducted on five female councilors of Cumilla City Corporation out of nine. Everybody called that their family always help them. They do not face any family related barrier in performing their duties and responsibilities. Specially husband's elected representatives strongly support them.

\section{Female councilor's response about social obstacles in performing duties $\mathcal{E}$ responsibilities}

Man lives in a society. Society is the working ground of female councilors. Society' demand and problem always influence them in doing work. From this study, it is observed that female councilors do not face any societal problems. Social people always help them in performing their duties.

\section{Female councilor's response about the political problem to participate in City Corporation election}

Women elected representative faced some problems before and during election. Political problem is one of them. Four respondents called that they did not face any political problems before and during election. But politics and political persons helped them before and during election. Finally a single councilor called that he faced some political problem during election.

Figure 5. Responses regarding political problem.

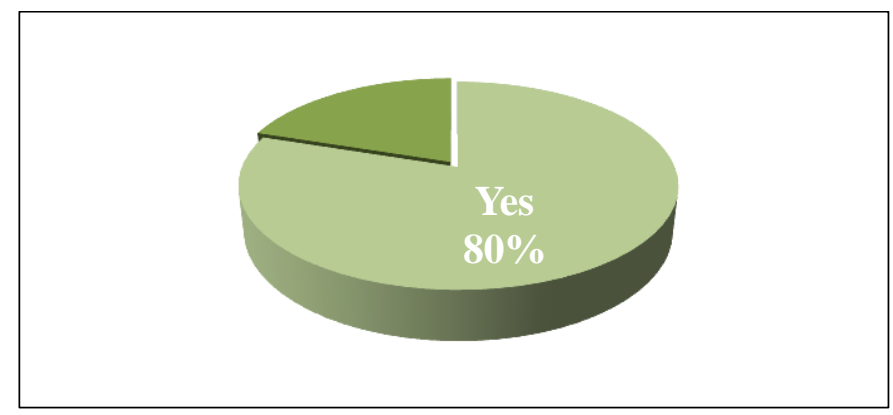

\section{Female councilor's response about political obstacles in performing duties}

Women councilors perform various activities in his constituency. Sometimes, they face some political problem. Two female councilors called that they face high level political problem. Specially, competitor of other party and ruling party create various problem in their working system. One person called he faces political problem moderately. Finally, a single female called that he faces little political problem in her locality. Everybody helped her in performing her duties and responsibilities. 
Figure 6. Responses regarding political obstacles in performing duties

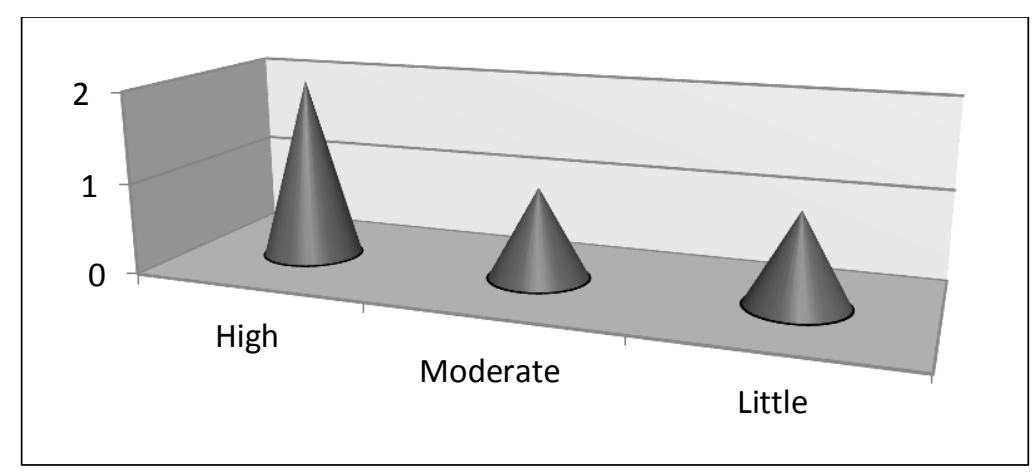

\section{Female councilor's response about male colleague's dominance in the decision-making of City Corporation}

As people's representative, female councilor has to perform their work with their male colleagues. By this chance they always try to dominate them in decision making of City Corporation. $20 \%$ female word Councilor said that they are highly dominated by their male colleague. $40 \%$ women representatives accused that they are highly and $20 \%$ are moderately dominated in various sectors especially in terms of decision-making process. Other 10\% councilor said that they are slightly dominated and rest of $10 \%$ informed that most of the times they are free from male dominance Because of their working experience.

Figure 7. Responses regarding dominance in decision-making.

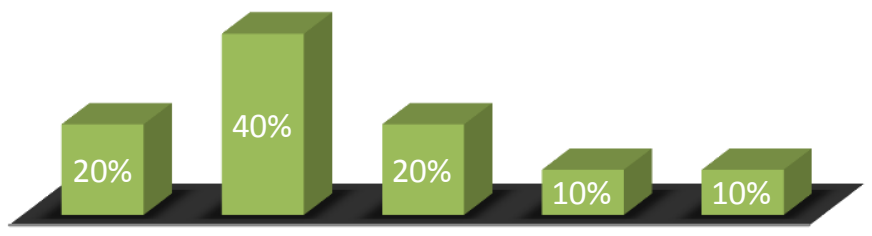

\section{Female councilor's response about the financial obstacles of women councilor}

As people representatives, mayor and male Councilors' get various types of budget for improving their certain area but female councilors do not get such budget. They have to depend on Mayor and male councilor. In fact, female 
councilors are elected from three wards, from all the ward's people demanded many privileges but they cannot provide any opportunity to the people like male councilor. In the meanwhile, their birth certificate providing power has been lost.

\section{Main barriers for non-participation of women representatives in local government.}

Though central level politics of Bangladesh are explored by women such as leader of ruling party, chairperson of opposition party, speaker of National parliament etc. all are women. But in local politics they are not explored themselves. Cumilla City Corporation has 27 wards but there is no elected women in general seat without reserved seat. They have deducted various reason behind this, $40 \%$ respondents said that lack of awareness about women right is major reason. $40 \%$ respondents think that lack of education is main reason and $20 \%$ respondents opined that patriarchal society is responsible for non-participant of women in local government.

Figure 8. Responses regarding main barriers of representation.

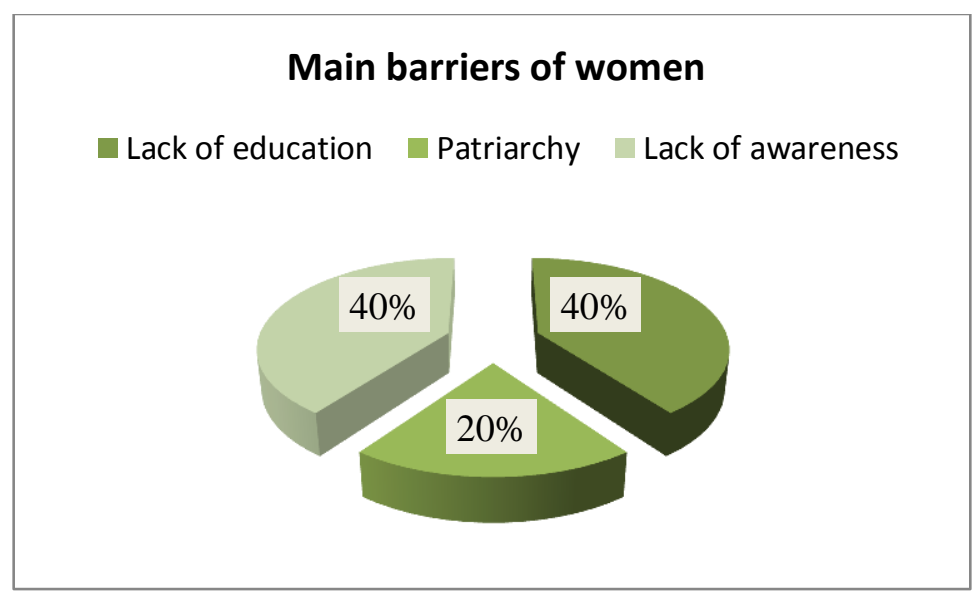

\section{Level of promise is fulfilled by elected representatives}

Female Reserved seat in city Corporation is not like parliament reserved seat, because here female councilors have to participate in direct election and compete with another female candidate. Finally, they are elected by general people. Before election they promised to voter/general citizens. They admitted that they are not fully fulfilling their election manifestos. No one tell us that, they fulfill their manifesto perfectly. $30 \%$ female councilor informed that they 
could execute their manifesto in very good way by others support. A percent of $30 \%$ fulfill in a good way and other the biggest ratio $40 \%$ respondents said that they can fulfill their manifesto on an average.

Figure 9. Responses regarding promise fulfillment.

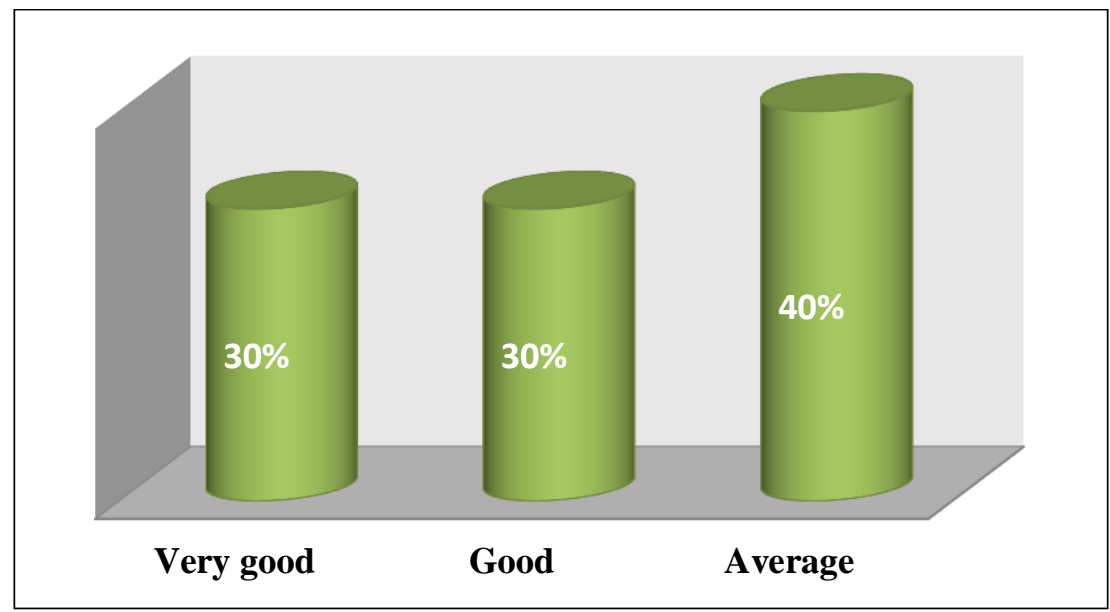

\section{Opinion of respondents about the necessity of women councilor in city corporation}

Respondents expressed various types of reactions about the necessity of women councilor in city Corporation. $22 \%$ respondents said that female councilor is highly needed because female citizens can access easily to the female councilors. $35 \%$ respondents said that female councilor needed because when both male and female councilors work combinedly it will be helpful to the local people. But 43\% respondents think that there is no necessity of female councilor because:

$>$ They have no power to do anything.

$>$ They do not get enough finance to serve the people.

$>$ There election area is too big than male councilor, that's why it is not possible by them to control those areas.

$>$ They have no capability for doing work.

$>$ They have no experience and training. 
Figure 10. Responses regarding necessity of women councilor.

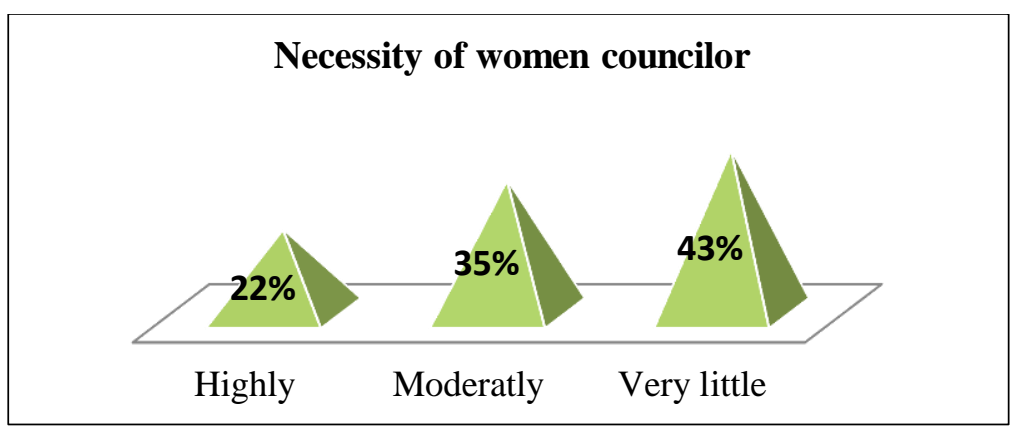

\section{Level of satisfaction about the roles/activities of women representatives}

There is a variation in the level of people satisfaction about roles/activities of women representatives. Above figure shows that only 13\% citizens are highly satisfied because they get enough service. $22 \%$ citizens are satisfied where $42 \%$ respondents informed that they are moderately satisfied by female councilor's activities because they can easily meet female councilor than male councilor. $12 \%$ respondents said that they are somehow satisfied and $10 \%$ said that this is no need of female councilors.

Figure 11. Responses regarding satisfaction about the roles/activities of women representatives.

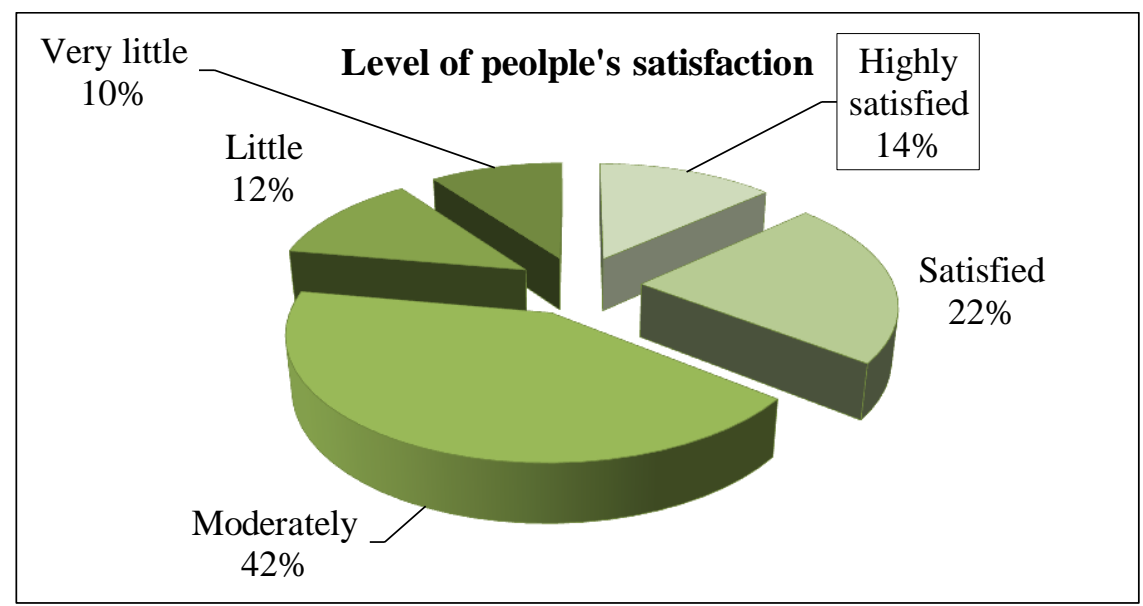




\section{Recommendations and final observations}

The study summarizes a number of propositions like change the present rules and regulation $(87 \%)$, increase financial support of female councilors than male councilors $(92 \%)$ because they are elected from three wards, where male councilors elected from only one ward. Reduce political barriers $(75 \%)$, combat gender inequality $(68 \%)$, ensure equality of women's councilors like male councilors $(70 \%)$ because they do not get equal opportunity (sometimes they are ignored as a female), consider as a people representatives $(63 \%)$, eliminate the dominance of male councilors $(79 \%)$, both in decision making and other related sectors $(88 \%)$, representatives wanted to specify their own activities in order to performing their duties properly and reduce clash with male councilor $(46 \%)$, representatives demanded to increase their honorarium because they are the councilor of three words not one ward. Finally, $55 \%$ of the councilors demanded that their security system must be ensured.

Figure 12. Summary of recommendations

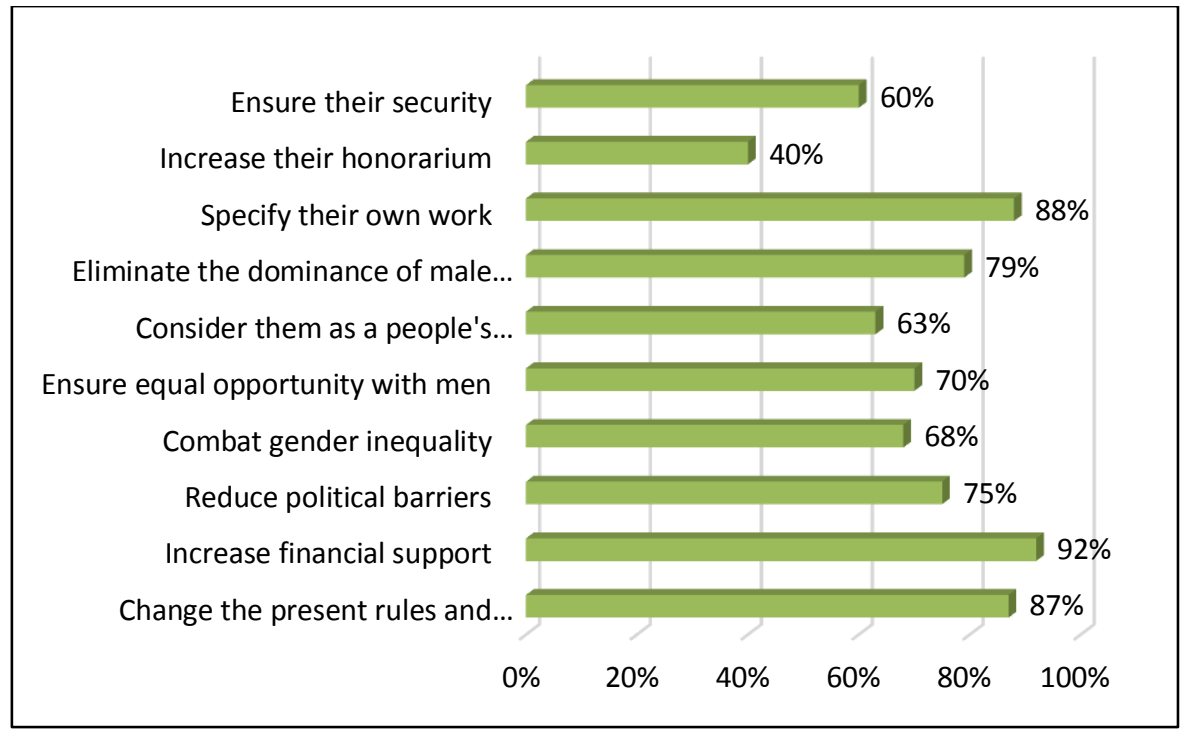

Women's equal involvement in political life plays an essential role in the overall procedure of the development of women. It is not simply a requirement for simple fairness or democracy although can also be perceived as an essential situation for women's benefits to be taken into consideration (Khan \& Ara, 2006). Without the lively involvement of women and the integration of women's viewpoint at all points of decision-making, the aims of parity, progress and harmony cannot be attained. The government inspires females to connect in politics as it considers that females become authorized, if they are capable to contribute in decision making similarly with males. 
The respondents expressed ways of empowerment can the best option for changing the scenario of lack of political empowerment of women including ensure security, increase honorarium, specify their work, eliminate dominance, recognition or consideration as peoples representative, ensure equal opportunity, combat gender inequality, reduce party political barrier, increase financial support and finally changes in existing rules and regulation.

\section{References}

Chowdhury, M. S., \& Aktaruzzaman, M. (2016). Citizen participation in urban local government: a case study of Kanaighat Paurashava in Bangladesh. Commonwealth Journal of Local Governance, (19), 119.

Chowdhury, N. (2002). The Implementation of Quotas: Bangladesh Experience-Dependence and Marginality in Politics. International IDEA Workshop "The Implementation of Quotas: Asian Experiences," Jakarta, Indonesia, September (Vol. 25).

Hossain, A. Z. (2015). Women empowerment in rural local government of Bangladesh. International Journal of Innovation and Applied Studies, 10(2), 584.

Hasan, S. (2007). Women in Bangladesh Local Government: A Study of Gram Sarkar. Dhaka: AH Development Publishing House.

Khan, M. M., \& Ara, F. (2006). Women Participation and Development in Local Government: Bangladesh Union Parishad Perspective. Asian Affairs, 29(1), 73-92.

Moin, J. (2011). Empowerment of Women and Their Participation in Local Government Politics. Dhaka: A H Development Publishing House.

Muhammed, M. H. (2017). Womens Political Participation in Local Government in Ethiopia: The Case of Two Districts in Ambara Regional State (Master's thesis, The University of Bergen).

Panday, P. K. (2008). Representation without participation: Quotas for women in Bangladesh. International Political Science Review, 29(4), 489-512.

Panday, P. K. (2013). Women's Political participation in Bangladesh: Institutional Reforms, Actors and Outcomes. NY: Springer.

Panday, P. (2016). Women's Empowerment in South Asia: NGO Interventions and Agency Building in Bangladesh. New York: Routledge.

Rahman, M. (2015). Empirical Evidence on How Women Leaders Changing Governance in the Grassroots Based Local Government of Bangladesh. Jurnalul Practicilor Comunitare Pozitive, 15(3), 38-56.

Sarker, J. (2018). Participation of Female Vice-Chair in decision-making process at Upazila Parishad, Bangladesh. Retrieved from: http://www.northsouth.edu/newassets/files/ppgresearch/ppg-7th-batch/JuthikaSarker_final_thesis.pdf

Siddika, A. \& Rahman, M. M. (December 30, 2010). Women in Local Government. The Daily Star. Retrieved from: https://www.thedailystar.net/news-detail-167964

Sun, T. W. (2004). Gender representation in politics and public administration: Taiwan and Asian countries. In Revised version of paper presented at the 18th Conference of International Association of Historians of Asia (LAHA), December (pp. 6-10).

Taskin, T. (2015). Women in urban local governance: A study on Dhaka city corporation (Doctoral dissertation, University of Dhaka).

UN (1992). Women in Politics and Decision-making in the Late Twentieth Century: A United Nation's Study. Dordrecht: Martinus Nijhoff Publishers. 
Ullah, M. W. (2018). Local Government in Bangladesh: Women's Participation and Empowerment. International Journal of Natural and Social Sciences, 5(4), 99-107.

Zaman, F. (2007). The nature of political empowerment and gender in local governance: A comparative study of Dhaka city corporation and Narayangonj municipality. Bangladesh eJournal of Sociology, 4(1), 49-72.

Zaman, F. (2012). Bangladeshi women's political empowerment in urban local governance. South Asia Research, 32(2), 81-101.

Election Commission (2019). Election commission report of Bangladesh-2019. Dhaka: Election Commission.

GoB (2016). Constitution of people's Republic of Bangladesh.

*** (2018). Bangladesh top gender equal country in South Asia. (Dec 19, 2018). Prothom Alo, Retrieved from: https://en.prothomalo.com/bangladesh/news/188311/Bangladeshtop-gender-equal-country-in-S-Asia 